\title{
The Effect of Speed and Accuracy in Accounting Information Systems on Financial Statements Content in Jordanian Commercial Banks
}

\author{
Fares Jamiel Hussein Alsufy ${ }^{1}$ \\ ${ }^{1}$ Faculty of Business, Isra University, Amman, Jordan \\ Correspondence: Fares Jamiel Hussein Alsufy, Faculty of Business, Isra University, Amman, Jordan. E-mail: \\ fares.alsufy@iu.edu.jo
}

Received: April 20, 2019

Accepted: May 16, 2019

Online Published: July 15, 2019

doi:10.5539/ijbm.v14n8p160

URL: https://doi.org/10.5539/ijbm.v14n8p160

\begin{abstract}
Several studies have emphasized the importance of accounting information systems all over the world with different views. The aim of this study is to determine the effect of accuracy and speed of accounting information systems towards financial content among Jordanian commercial banks. A descriptive approach was employed to achieve the objectives of the study. Survey questionnaire was used to collect data from a selected sample of 13 banks. the sample was selected from top and middle Management levels as these levels represents the perfect group for making decision's related to quality of financial reports and its Relationship with accounting information systems, 130 questioners were distributed with average 10 questioners for each bank and 126 questioners were got response. The results reveal that there is significant effect of accuracy and speed of accounting information systems in financial content among Jordanian commercial banks.
\end{abstract}

Keywords: accuracy, speed, accounting information systems, Jordanian commercial banks

\section{Introduction}

The need for accounting information systems increase due to Increased different business volume and appearance of new Technology which affects directly the accounting information systems (Al Saqa, 2016), and this effect reflected on accounting in General as the accounting information systems already exist, also It has big evolution after the end of the second world war till the Current period picture now because of reliance on technology in Financial reports preparation (Alikhani, 2014).

The existence of accounting information systems is one of the most Important controls to provide high quality financial information (Medh, 2009), the previous studies concentrated on utilizing Accounting information system rule in decision making process form top management in banks due to its rule in improving Financial information quality.

The importance of this study comes from the fact that the accounting information systems one of strategic considerations that the banks rely on in improving financial information in order to Obtain relevant decisions and the accuracy and speed of the accounting information systems is one of the basis of financial information because its collect the information that reflected in financial Statements, so it should increase organization knowledge in this regard to find solutions for issues that may it encounters And to avoid it, inaccuracy in accounting information may leads to verification in these information because of mistakes in information and that leads to inaccurate future forecasts, also the inaccuracy in information prepared to management team and that's related to mistakes in accounting measurement or problem in information communication to decision maker (Abu Nassar, 2016).

The timeless and speed in information communication to management is critical for project management (Qaod, 2007) and if we considered the accuracy from major purposes for accounting Information system also the timeless and speed in information preparation and presentation along with accuracy is critical also, Some people see that the speed and timeless more important than accuracy because information timeless enable management for pricing, deals, decisions making without fear from unpredicted Risks, also capital structure information availability on time protect Project management from unsuitable financing decision's making (Burtuon, 2007). the management may raise debt financing with A lot of interest without any actual need for these debts. To 
achieve.

Speed and timeless goal projects may go to obtain costly hardware to record financial transactions and to prepare financial Reports timely, and that maybe not suitable for all cases and Situations, it should be from the beginning preparing the accounting system that provides project management with its need Form financial information and that matter is applicable for either small or big projects due to risk of making decisions without data Reference (Alsaqa, 2016).

Howari and others, (2016) study indicated the rule of accounting information system Through (human capital, using computers, compliance with IFRS) in financial statements content activation, also Alsaqa (2016) study indicated the effect of electronic accounting information systems in Improving company's financial performance through the presence of accounting information quality (Relevance and Faithfull representation) in addition to reliability.

In Vencen,2016 study the researcher explains the effect of accounting information system on small, medium companies and the possibility of utilizing the effectiveness of these systems to strength management efficiency, cost reduction, and how to help management to make relevant decision's, the same point that and (Abu Nassar, 2016) refers to (Nabizadeh, 2014)

The study subject and problem here is explaining the effect of speed and accuracy of accounting information systems on the content of financial statements and that comes through providing answers on the two below main questions and concerns:

1 - What is effect of accuracy in accounting information systems on the content of financial statements in Jordanians commercial banks?

2 - What is effect of Speed in accounting information systems on the content of financial statements in Jordanians commercial banks?

\section{Research Methodology}

\subsection{Study Population and Sample}

The study population consists of all 13 Jordanian commercial banks managers, the sample was selected from top and middle Management levels as these levels represents the perfect group for making decision's related to quality of financial reports and its Relationship with accounting information systems, 130 questioners were distributed with average 10 questioners for each bank and 126 questioners were got response with $97 \%$ from distributed questioners, and 2 questioners were excluded because they not appropriate for statistical analysis purposes.

\subsection{Study Model}

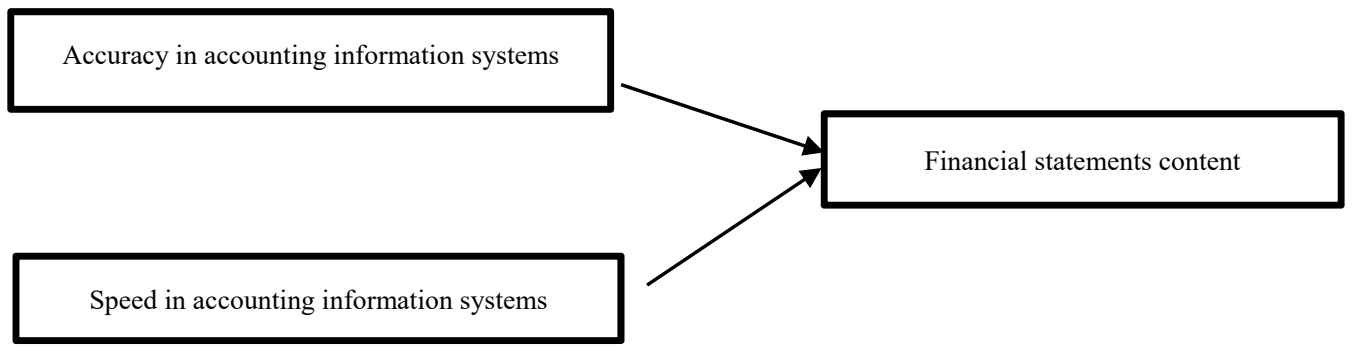

\subsection{Study Hypotheses}

The first main hypotheses: there is no statistically significant effect at (a>.05) for accuracy in accounting information systems on financial statements content.

The second main hypotheses: there is no statistically significant effect at (a>.05) for speed in accounting information systems on financial statements content.

\section{Data Analysis, Discussion, Results Presentation}

\subsection{Data Analysis and Hypotheses Testing}

This chapter presents description and analysis for study data, as it provides description for study sample 
attributes, and description for its variables and the relative importance for study paragraphs and hypotheses testing and related comments taking into the consideration that 130 questioners distributed and 130 back and the submitted is 126 .

\subsubsection{Study Tool Consistency Test}

The internal consistency was computed using Cronbach's Alpha and the results was as the below:

Table 1. Internal consistency values for study tool paragraphs

\begin{tabular}{lll}
\hline Number & Dimension & Alpha Value \\
\hline 1 & Accuracy & 0.848 \\
2 & Speed & 0.905 \\
& Total & $\mathbf{0 . 8 9 7}$ \\
3 & Financial statements content & 0.908 \\
& All paragraphs & $\mathbf{0 . 9 2 9}$ \\
\hline
\end{tabular}

We concludes that consistency values using Alpha factor were ranged from (.848-.908), and its more than (.6), and that is indicator for study tool paragraphs consistency and study tool reliability and creditability for statistical analysis run.

\subsubsection{Study Sample Attributes Description}

This part includes the defining and demographic factors for sample tool population like: Six, age, current employment, education, field of study)

Table 2. Description of the study sample according to the demographic

\begin{tabular}{|c|c|c|c|c|}
\hline Variable & Category & Attribute & Frequency & Percentage \\
\hline \multirow[t]{3}{*}{1} & Sex & Male & 95 & $\% 75.40$ \\
\hline & & Female & 31 & $\% 24.60$ \\
\hline & & Total & 126 & $\% 100$ \\
\hline \multirow[t]{5}{*}{2} & Age & Less than 25 & 44 & $\% 37.90$ \\
\hline & & From 25 To 35 & 34 & $\% 27$ \\
\hline & & From $35-45$ & 26 & $\% 20.60$ \\
\hline & & 45 and More & 22 & $\% 7.5$ \\
\hline & & Total & 126 & $\% 100$ \\
\hline \multirow[t]{7}{*}{3} & Current Job & Customer Service & 21 & $\% 16.67$ \\
\hline & & Accountant & 14 & $\% 11.11$ \\
\hline & & Head of Deposits Department & 14 & $\% 11.11$ \\
\hline & & Assistant Manager & 14 & $\% 11.11$ \\
\hline & & Cashier & 53 & $\% 42$ \\
\hline & & Other & 10 & $\% 8$ \\
\hline & & Total & 126 & 100 \\
\hline \multirow[t]{5}{*}{4} & Education & Diploma & 10 & $\% 7.94$ \\
\hline & & $\mathrm{BA}$ & 112 & $\% 88.89$ \\
\hline & & Master & 4 & $\% 3.13$ \\
\hline & & Ph.D. & 0 & 0 \\
\hline & & Total & 126 & 100 \\
\hline \multirow[t]{7}{*}{5} & Field Of Study & Accounting & 86 & $\% 68.25$ \\
\hline & & Finance & 14 & $\% 11.11$ \\
\hline & & Business Administration & 6 & $\% 4.76$ \\
\hline & & MIS & 0 & 0 \\
\hline & & AIS & 5 & $\% 3.97$ \\
\hline & & Other & 15 & $\% 11.91$ \\
\hline & & Total & 126 & 100 \\
\hline
\end{tabular}

1 - Sex: as it appear from the table () that males category is the largest category with $(75.4 \%)$ while females 
category is around $(25 \%)$ because that most of employees in banks actually males.

2 - Age: As it appears from the table () that ( less than 25) category is largest one with (34.9\% ), it means that most of the sample individuals is young people

3 - Current Job: From the table () we found that most of sample individuals from cashier category with (42\%) after that customer service with (16.67\%) from the sample.

4 - Education: From the table () BA holders is the largest category with (88.89\%) then Diploma with $(7.94 \%)$ which means good indicator for people under research for questions answering.

5 - Field of study: from the table () it appears that accountants' category is $(68.25 \%)$ and its good indicator as the individuals must have appropriate and adequate knowledge for providing answers for questions.

\subsubsection{Study Questions Analysis}

To obtain information about sample individuals thinking about study variables model based on data collected about speed and accuracy in accounting information system effect on financial statements content we used means, standard deviations, rank

Significance level, application level and the results were as following:

a. Accuracy

Table 3. Means, standard deviations, level for accounting information systems accuracy

\begin{tabular}{|c|c|c|c|}
\hline No. & Paragraph & Mean & $\begin{array}{l}\text { standard } \\
\text { deviation }\end{array}$ \\
\hline 1 & $\begin{array}{l}\text { There's Little possibility for errors and discrepancies between repor } \\
\text { and system output. }\end{array}$ & $r+54$ & 1.29 \\
\hline 2 & The accounting information system output is reliable & 3.30 & 1.55 \\
\hline 3 & $\begin{array}{l}\text { The accounting information system provides reliable and accurate } \\
\text { information for decision making }\end{array}$ & 3.53 & 1.33 \\
\hline 4 & There're controls in accounting information system for input process & 3.73 & 1.25 \\
\hline \multirow[t]{2}{*}{5} & $\begin{array}{l}\text { The accounting information system provides information on time wher } \\
\text { it is needed }\end{array}$ & n 3.88 & 1.18 \\
\hline & Total & 3.71 & \\
\hline
\end{tabular}

Table 3 shows that the computational circles of the sample responses ranged between (3.30- 4.88) with the highest computation (3.88) and the standard deviation (1.18) for paragraph (5) which is " The accounting information system provides information on time when it is needed ", The accounting information system output is reliable ".

\section{b. Speed in accounting information systems}

Table 4. Means, standard deviations level for accounting information systems speed

\begin{tabular}{llcc}
\hline No. & Paragraph & Mean & $\begin{array}{c}\text { standard } \\
\text { deviation }\end{array}$ \\
\hline 1 & The input process in the accounting information system on time and 3.11 & 1.47 \\
& within target. & 1.50 \\
2 & The updates and corrections in accounting information system on time. 3.04 & 1.58 \\
3 & The reports were prepared as requested & 3.39 & 1.29 \\
4 & There're no complaints from customers about service delay & 4.02 & 1.28 \\
5 & The accounting information system reduced routine procedures & 3.84 & 3.71 \\
\hline
\end{tabular}

Table 4 shows that the computational circles of the sample responses ranged between (3.04- 4.02) with the highest computation (4.02) and the standard deviation (1.58) for paragraph (4) which is "There're no complaints from customers about service delay", The lowest mean (3.04) for paragraphs (2) which is "The updates and corrections in accounting information system on time". 


\section{c. Dependent variable: Financial statements content}

Table 5. Means, standard deviations level for financial statements content

\begin{tabular}{|c|c|c|}
\hline$\underline{N}$ & Paragraph & standard deviation \\
\hline 1 & $\begin{array}{l}\text { The financial statements content provides economic value through the } 3.96 \\
\text { distributed reports and information for all interested parties. }\end{array}$ & 1.05 \\
\hline 2 & $\begin{array}{l}\text { The financial statements content provide investors transparency and fairness } 3.71 \\
\text { standard through obtaining information in the same time }\end{array}$ & 1.32 \\
\hline 3 & $\begin{array}{l}\text { The financial statements content provides investors with relevant information } 3.62 \\
\text { that they wait to make various decision's }\end{array}$ & 1.25 \\
\hline 4 & $\begin{array}{l}\text { Financial statements content provides investors with accurate information that's } 3.91 \\
\text { add value to their decision making process }\end{array}$ & 1.16 \\
\hline 5 & Financial statements content provides information on time & 1.16 \\
\hline 6 & The financial reports faithfully represents bank financial status & 1.27 \\
\hline 7 & $\begin{array}{l}\text { The analytical structure for the data flow through its various channels in value } 3.76 \\
\text { added manner that meet all investors need and as their per understanding }\end{array}$ & 1.24 \\
\hline \multirow[t]{2}{*}{8} & $\begin{array}{l}\text { There's diversification in financial reports information that allows for investors } 3.74 \\
\text { to understand the bank financial position and the continuous updates and } \\
\text { changes. }\end{array}$ & 1.19 \\
\hline & Total & \\
\hline
\end{tabular}

Table 5 shows that the computational circles of the sample responses ranged between (3.62-3.96) with the highest computation (3.96) and the standard deviation (1.05) for paragraph (1) which is " The financial statements content provides economic value through the distributed reports and information for all interested parties.", The lowest mean (3.62) for paragraphs (2) which is " The financial statements content provides investors with relevant information that they wait to make various decision's".

\subsubsection{Hypotheses Analysis}

\subsubsection{The first main hypotheses:}

There is no statistically significant effect at (a>.05) for accuracy in accounting information systems on financial statements content.

Table 6. Effect of accuracy in financial statements content

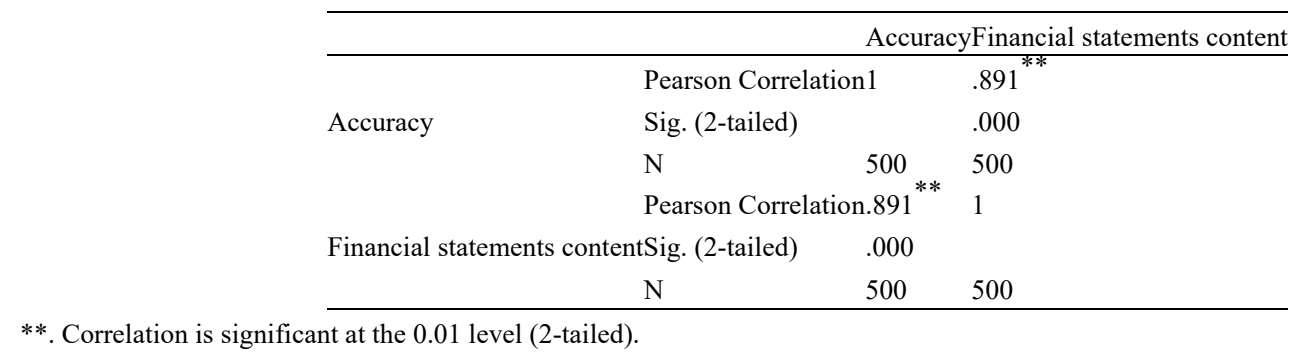

Table 6 shows that after the independent variable (Accuracy), that significance was $(0.00)$ less than $(0.05)$, indicating that relationship between Accuracy and Accounting information systems of financial statements content.

3.1.4.2 The second main hypotheses:

There is no statistically significant effect at (a>.05) for accuracy in accounting information systems on financial statements content. 
Table 7. Effect of accuracy in financial statements content

\begin{tabular}{llll}
\hline & & Speed & Financial statements content \\
\hline \multirow{3}{*}{ Speed } & Pearson Correlation & 1 & $.917^{* *}$ \\
& Sig. (2-tailed) & & .000 \\
& $\mathrm{~N}$ & 500 & 500 \\
& Pearson Correlation & $.917^{* *}$ & 1 \\
Financial statements content & Sig. (2-tailed) & .000 & \\
& $\mathrm{~N}$ & 500 & 500 \\
\hline
\end{tabular}

**. Correlation is significant at the 0.01 level (2-tailed).

Table 7 shows that after the independent variable (Speed), that significance was $(0.00)$ less than $(0.05)$, indicating that relationship between Accuracy and Accounting information systems of Financial statements content.

Multiple Regression test:

Table 8. Effect of accuracy and speed in financial statements content

\begin{tabular}{lllllll}
\hline & Model & Sum of Square & Df & Mean Square & $F$ & Sig. \\
\hline 1 & Regression & 284.03 & 3 & 94.68 & 1181.39 & 0.00 \\
Residual & 39.75 & 496 & 0.07 & & \\
Total & 323.78 & 499 & & & \\
\hline
\end{tabular}

Table 7 shows that the value of $F$ is (981.73) and the statistical significance level is $(0.00)$ and thus is less than (0.05). Thus, the null hypothesis was rejected, and the alternative hypothesis is accepted. There is effect of (Accuracy and speed of accounting information systems) at the significant level $(a \leq 0.05)$ on in financial statements content.

\section{Conclusion}

The aim of this study was to investigate the effect of accuracy and speed of accounting information systems in financial statements content. The results indicate that all these factors are affected the financial statement content positively.

\section{References}

Abu, N. M. (2016). Accounting Darria. Dar Wael Publishing and Distribution, Amman: Jordan.

Alikhani, H., Ahmadi, N., \& Mehrava, M. (2013). Accounting Information System Versus Management Information System. European Online Journal of Natural And Social Sciences, 2, 359-366.

Al-Sakka, M. (2016). Assessment of the quality of computerized accounting information systems and their impact on improving the financial performance of the Palestinian Ministry of Finance.

Amari, S. (2013). Effect of applying corporate governance mechanisms on the quality of accounting disclosure Case Study of the Office of Promotion and Real Estate Management of the State of Bouira.

Gujarati, D. N. (2004). Basic Econometrics (4th ed.), UNA, New York: McGraw Hill.

Hassan, A. T. A. (2013). The employment of accounting information systems Zakat institutions and their dirham in operational efficiency. Zakat Institute of Sciences, Khartoum from 28 April to 2 May 2013.

Hawari et al. (2016). Impact of Accounting Information System on the Effectiveness of Media Content of Financial Statements. Unpublished Master Thesis.

Hayali, W. (2007). The Accounting Theory of the Arab Open Academy in Denmark.

Matar, S. M., \& Mousa. (2012). The theoretical rooting of accounting professional practices. In the fields of presentation, measurement and disclosure (Dar Wael Publishing \& Distribution, Amman).

Nabizadeh, S. M., \& Omrani, S. A. (2014), Effective factors on accounting information system alignment: A step towards organizational performance improvement. International Journal of Scientific and Research Publications, 4(9), 1-5.

Nwinee, K., Akpos, Y., Vincent, G., \& Ibinabo, T. (2016). Impact of accounting information system on 
organizational effectiveness: A study of selected small and medium scale enterprises in Woji, Portharcourt. International Journal of Research, 3(1), 974-982.

Sekaran, U. (2003). Research methods for business (4th ed.). Hoboken, NJ: John Wiley \& Sons.

Siren, R. (2013). Quality Factors in Information Systems Applied in Telecommunications Companies. Damascus University Journal of Economic and Legal Sciences.

\section{Copyrights}

Copyright for this article is retained by the author(s), with first publication rights granted to the journal.

This is an open-access article distributed under the terms and conditions of the Creative Commons Attribution license (http://creativecommons.org/licenses/by/4.0/). 